\title{
Revenge of the Radical Right
}

\author{
Lenka Bustikova
}

\author{
Assistant Professor \\ School of Politics and Global Studies \\ Arizona State University \\ P.O. Box 873902 \\ Tempe, AZ 85287-3902 \\ Phone: 480-965-2912
}

Fax: 480-965-3929

lenka.bustikova@asu.edu

\section{Comparative Political Studies, forthcoming}

November 4, 2013

* Lenka Bustikova received her Ph.D. from Duke University in 2012. She is an Assistant Professor at the Arizona State University. Her work was published in "Journal of the Contemporary European Studies," "Communist and Post-communist Studies" and the "Journal for the Study of Anti-Semitism".

Acknowledgements:

The paper benefited from comments from: John Aldrich, David Art, Kai Arzheimer, Pablo Beramendi, Valerie Bunce, Cristina Corduneanu-Huci, Grzegorz Ekiert, Anna Grzymala-Busse, Petra Guasti, Olga Gyarfasova, Herbert Kitschelt, Judith Kelley, Zdenka Mansfeldova, Nikolay Marinov, Bonnie Meguid, Csaba Nikolenyi, David Ost, Jerry Reiter, Karen Remmer, Arturas Rozenas, Hermann Schmitt, David Siroky, Milada Vachudova, Cees van der Eijk and three anonymous reviewers. Previous versions of the paper was presented at The Institute of Sociology, Prague 2007; APSA 2011; MPSA 2011; 19th International Conference of Europeanists, Boston, 2012, University of Mainz 2012; Democracy with Edges Conference, Yale University, 2012 and 2nd European Conference on Comparative Electoral Research, 2013. 


\title{
Revenge of the Radical Right
}

\begin{abstract}
What explains the success and failure of radical right parties over time and across countries? This paper presents a new theory of the radical right that emphasizes its reactive nature and views it as backlash against the political successes of minorities and concessions extracted on their behalf. Unlike approaches that focus on competition between the extreme and mainstream parties, the theory stresses the dynamics between radical right and non-proximate parties that promote minority rights. Most notably, it derives the salience of identity issues in party politics from the polarization of the party system. The theory is tested with a new party-election-level data set covering all postcommunist democracies over the past twenty years. The results provide strong support for the theory, and show that the rise and fall of radical right parties is shaped by the politics of minority accommodation.
\end{abstract}

Keywords: radical right parties, ethnic minorities, coalitions 
What explains variation in the electoral success and failure of radical right parties? This article provides a new theory of why radical right parties succeed in some countries and fail in others, and why the electoral fortunes of radical right parties fluctuate within countries over time. Contrary to other approaches that focus on institutions, economic grievances, mainstream party behavior, legacies and corruption, my theory suggests that radical right parties respond to the political successes of minorities, and seek to reverse their political gains. The proposed model endogenizes issue salience in party competition to the spatial positions of parties on non-economic issues. It shows that the accommodation of politically organized minorities polarizes party systems, and explains variation in the electoral success of radical right parties. ${ }^{1}$

The radical right party family is the fastest growing party family in Europe (Mudde, 2007). In Western Europe, radical right parties emerged in the late 1980s and have grown in importance ever since (Arzheimer, 2009; Art, 2011; Kitschelt, 2007; Ivarsflaten, 2008). In Eastern Europe, most radical right parties emerged in the wake of 1989, and their electoral fortunes have varied greatly across countries and time (Greskovits, 2007; Kopecky \& Mudde, 2003; Minkenberg, 2009; Mudde, 2005; Pop Eleches, 2010; Ramet, 1999; Tucker, 2005; Vachudova, 2008). ${ }^{2}$ For example, in Croatia, Estonia, Latvia, Poland, Serbia and Slovakia, radical right parties have been present in governing coalitions since the founding elections and have significantly shaped minority policies. But radical right parties have either been altogether absent or largely unsuccessful in Albania, Czech Republic, Moldova, Montenegro and Ukraine.

Throughout the 1990s, the study of radical right parties in Eastern Europe was largely neglected, as most scholars focused on the success and failure of newly emerging (mainstream) political parties, with some attention also paid to political extremism on the 
left (Ishiyama, 1997; Grzymala-Busse, 2002). After a decade of transition-oriented literature, the focus slowly shifted to the study of extremism on the right, and the literature on radical right parties in Eastern Europe has slowly begun to flourish (Ekiert, 2006; Lewis, 2009; Ost, 2005; Held, 1996; Hockenos, 1993; Minkenberg, 2002; O’Dwyer \& Schwartz, 2010; Shafir, 2002). Building on these excellent studies, this article fills a gap by developing a novel theoretical explanation for variation in the electoral success of radical right parties across countries and over time, and by providing a systematic time-series analysis of the theory's implications in all post-communist democracies.

The proposed model differs from both supply and demand side theories (Eatwell, 2003; Norris, 2005; Van der Brug et al., 2005). Demand side theories have focused on psychological sentiments, institutional arrangements, historical processes and economic grievances. Although adverse economic conditions can certainly create grievances that may later facilitate the rise of radical parties and contribute to their survival, grievances are too static to explain cross-national volatility over time (Betz, 1994; Golder, 2003; Kitschelt \& McGann, 1995; Swank \& Betz, 2003; c.f. Arzeheimer, 2009:274; Givens 2004).

Supply side theories and institutional theories predict radical party support to vary in tandem with mainstream party strategies, competition between proximate parties, perceptions of future coalition bargaining, internal party organizations, opportunity structures and party system institutions (Adams et al., 2006; Carter, 2005; Kedar, 2005; Meguid, 2005). Party-oriented, supply-side accounts mostly treat salience as exogenous to the party system and have tended to overlook the role of parties at the other ideological 
extreme. My theory views these parties, which Sartori (1976) called "bilateral opposites", as vital to explaining variation in radical right support.

Whereas earlier supply-side research has generally treated the radical right's electoral prospects as a function of either mainstream or proximate party strategies, I argue that temporal variation in the success of radical right parties is driven by the success of ethnic and socially liberal parties on the left. The presence and actions of the bilateral opposite polarizes the party system and increases issue salience. Contrary to economic issues where parties can project positions that are salient, yet also centrist, noneconomic issues become salient when parties polarize; that is, when politically organized minorities ascend to power and governments pursue pro-minority policies.

Radical right parties arise as a backlash against concessions extracted by politically organized ethnic and social minorities. When politically mobilized minorities extract concessions and accommodation increases, the theory predicts that radical right parties will gain in strength. Conversely, when the status quo is preserved or accommodation recedes, radical right parties are predicted to lose strength. The article tests these predictions using original party-level electoral data covering all postcommunist democracies from 1990-2012. The results strongly support these hypotheses, and indicate that the rise and decline of radical right parties is shaped by the electoral fortunes of bilateral opposite parties and the accommodation of minority groups.

In the next section, I define radical right parties, bilateral opposites and develop the theoretical argument. After introducing a new dataset and the methods, I discuss the statistical results and corroborative case study evidence. The last section concludes with a discussion of the theory's external validity and its contribution to understanding the roots of political extremism. 


\section{Defining Radical Right Parties}

Since identity policies exist on what is traditionally understood to be the right and the left, a useful party typology should place parties using their positions on identity issues. ${ }^{3}$ My classification system for the parties is built on the grid-group theoretical framework, first developed by Douglas (Thompson et al., 1990). Two ideological dimensions define this typology - radical nationalism and radical socio-cultural conservatism - and these dimensions correspond to two modes of social control: grid and group. The grid-group typology generates four ideal types of parties in a grid-group space.

A radical right party is defined as a party that scores high on social authoritarianism and nationalism (high grid and high group). These parties are either highly nationalistic and/or extremely socially conservative. If a party scores high on only one dimension and low on the other dimension, it is not classified as a radical right party. This applies for example to some of the communist parties who support social minorities and gender equality (low on grid) yet are nationalistic (high on group). ${ }^{4}$

The "bilateral opposite" of a radical right party is an ethno-liberal party, or a party that scores low on grid and group. Such parties often advocate ethnic quotas, minority autonomy in schooling, elevation of the minority language to the status of the official language, targeted access to state resources and preferential economic policies. ${ }^{5}$ Parties were classified using primarily three resources: expert surveys, party ideology and case studies. ${ }^{6}$

\section{- TABLE 1 HERE -}

Radical right parties in Croatia, Estonia, Latvia, Romania, Serbia, Slovakia and Slovenia have been steadily attracting some voter support since the early 1990s, although 
their electoral fortunes have fluctuated considerably across elections from five to forty percent of the popular vote. Elsewhere, such as Albania, Macedonia and the Czech Republic, radical parties emerged rapidly, only to disappear just as quickly, while in Moldova, Montenegro such parties never or hardly appeared at all. Table 1 shows how the strength of radical parties has varied considerably over time and across countries. The theory outlined in the next section offers an explanation for why.

\section{A Theory of the Radical Right}

The claim that radical right parties are not fond of minorities is not new, but we should not be blinded by the inflammatory nature of the rhetoric. I argue that voting for radical right parties does not originate in hatred against minorities, but rather in opposition to policies that accommodate their demands and the political advancement of minorities. The theory suggests that radical right parties respond to the electoral success of prominority parties, and therefore variation in minority political accommodation should predict change in electoral support for radical right parties.

The case of Macedonia illustrates this logic. In 2001, a brief but violent armed conflict erupted between the ethnic Albanian militants and the Macedonian government, and was settled by the Ohrid Agreement, which improved the status of Albanians within Macedonia. The agreement elevated the Albanian language to an official status and established an Albanian speaking university in Tetovo. In the 2002 elections, the dominant party (VMRO-DPMNE) lost, and was replaced by a coalition called "Together for Macedonia Alliance", which ruled together with the largest Albanian ethnic political party (BDI), and created pro-Albanian legislation. In the 2006 election, an extremist, 
nationalist wing split from VMRO-DPMNE and targeted "minorities with privileges" (a euphemism for Albanians) and entered the parliament with six percent of the votes.

Moderate parties may court politically organized groups that support the accommodation of minorities and advocate socially liberal policies to form governing coalitions. Change in accommodation and group status often result when minority representatives are elected or appointed into public offices and advance minority causes, typically in education and regional development. When this dynamic ensues, radical right parties benefit from the backlash against political concessions to minorities. Policy concessions result in programmatic divergence, and therefore salience can be derived from spatial polarization. When pro-minority advocates obtain government portfolios or seats in the parliament, they can extract state resources or policy concessions, which breeds resentment and mobilizes radical right voters and parties.

In this model, the electoral success of radical right parties is thus integrally tied to coalition politics. Although there is a large literature on the dynamics of coalition formation (Grzymala-Busse, 2001; Golder \& Conrad, 2010; Laver \& Schofield, 1990; Laver, 1998; Riker, 1962), this research has largely overlooked the effect of coalition participation on issue salience. Supply-side theories expect radical right parties to succeed most when identity issues are salient, and when radical parties are perceived as "owning" identity issues. Yet issue salience is typically treated as entirely exogenous to the political system (Colomer \& Puglisi, 2005; Smith, 2010) or as an outcome of party strategies designed to secure a competitive advantage (Belanger \& Meguid, 2008; Wilkinson, 2004; Wittenberg \& Kopstein, 2011).

My theory endogenizes issue salience, and argues that it is a function of the strength and the inclusion of ethno-liberal parties in governing coalitions, which polarize 
party systems. The salience of identity increases if the ethno-liberal party extracts policy concessions from its coalition partner or elevates minority representatives into positions of symbolic importance. Policies that privilege and elevate some groups over others magnify pre-existing grievances, fuel resentment and create a political backlash that benefits radical right parties. The simple formation of a governing coalition between a mainstream party and an accommodation-seeking party should therefore increase the probability of the radical right's success in the subsequent electoral cycle.

The case of Bulgaria illustrates the logic of the backlash against a junior coalition partner. Bulgaria did not produce a single radical right party until 2005 when the radical right ATAKA party emerged seemingly "out of nowhere" and gained eight percent of the vote. At the same time, Bulgaria signed the EU accession treaty and its economy was experiencing 7\% growth. ATAKA's success was not surprising when viewed in light of the theory. In the 2001 election, the Turkish ethnic party (DPS) was invited into the governing coalition and ethnic Turkish ministers became part of the cabinet for the first time since 1989. This allowed DPS to block policies aimed at trimming state subsidies for tobacco-cultivation, the occupational specialization of many Bulgarian Turks. DPS's growing influence in the Bulgarian political system led to a backlash. The newly founded ATAKA professed "ethnic minorities with privileged access to policy-making" to be their primary political target and received 21 seats in the parliament.

The theory generates three important observable empirical implications. The first, is that we should observe strong radical right parties after ethno-liberal parties gained votes in the prior election. This should follow if radical right parties arise as a backlash against the electoral strength of the ethno-liberal parties. The second implication is that radical right parties should become stronger after the ethno-liberal party has been 
included in a governing coalition and obtained a ministerial post, for this permits the ethno-liberal parties to influence policies and to access state resources. A third observable implication is that radical right parties should succeed in proportion to the ideological extremism of the ethno-liberal party in the previous electoral cycle. These implications can be expressed as three hypotheses:

Hypothesis 1: When the vote share of an ethno-liberal party in an election held at time $t$ - 1 increases, then the radical right party's vote share in elections at $t$ should also increase.

Hypothesis 2: The inclusion of an ethno-liberal party in a governing coalition at time $t-1$ increases the radical right party's vote share in elections at $t$.

Hypothesis 3: The inclusion of an ideologically extreme ethno-liberal party in a coalition in election $t-1$ increases the radical right party's vote share in elections at $t$.

In addition to these dynamic policy influences countries posses different structural propensities for the emergence of radical right parties. The theory suggests that the most important of these is a country's ethnic structure. The ethnic structure influences the prospects for the radical right party's success across countries in a counter-intuitive manner. In countries with small minorities, the accommodation of minority demands results in the minority's "status elevation." Radical right voters become irritated with the minority's political successes and aim to curb its further advancement. In countries with large minorities, however, change in the accommodation of a politically organized minority can significantly threaten the titular nationality with "status reversal" (Petersen, 2002). Voters vulnerable to status reversal have reason to fear their loss of ethnic dominance, and thus rally behind a large mainstream party with broad appeal that is deemed capable of containing the threat and unifying the titular nationality. Countries with smaller ethnic minorities are therefore actually more likely to have successful 
radical right parties, since providing seats and portfolios to a smaller minority group engenders more resentment among the majority, leading to a backlash that benefits radical right parties.

This prediction seems to contradict expectations from theories that associate larger minority groups and larger influxes of immigrants with increased political mobilization along ethnic lines (Dancygier, 2010; Golder, 2003; Olzak 1992: 35), but it is in line with studies that have found no relationship between the size of immigrant groups and the electoral success of radical right parties at the cross-national level (Lucassen and Lubbers, 2012; Norris, 2005).

In sum, the theory focuses on two important factors that help to explain the success of failure of radical right parties: (1) the ethnic structure, which determines the threat of status elevation, and influences the baseline propensity for the success of radical right parties across countries, and (2) minority accommodation and polarization, which determines the salience of identity issues and shapes the fortunes of radical right parties from one election to the next.

\section{Data Description and Estimation Strategy}

To investigate these hypotheses, I created an election-year-country dataset covering the period from the early 1990 s to the present for all post-communist democracies. ${ }^{7}$ The data set is structured as a quasi-time series of ninety-three parliamentary elections in seventeen countries from 1991 to 2012 and the dependent variable is the natural log of the radical right party's combined vote share in elections held at time $t$.

To examine the backlash logic embedded in these hypotheses, I utilize three measures. The first measure, associated with Hypothesis 1, is the log of the ethno-liberal 
party's vote share in the previous electoral cycle. The second measure, to explore Hypothesis 2, accounts for the access of the ethno-liberal party to policy making and state resources using an indicator of its participation in the governing coalition during the previous cycle. Although the ethno-liberal parties must be strong enough to cross the electoral threshold in order to be considered for participation in a coalition, it is not the case that stronger ethno-liberal parties are more or less likely to be invited to join coalitions. For this reason, it is important to measure the strength of the ethno-liberal parties in terms of vote shares and their participation in governing coalitions independently. I also examine the effect of ethnic structure to test the claim that support for radical right parties is stronger in countries with smaller minorities. ${ }^{8}$

To investigate Hypothesis 3 - that radical right parties arise as a backlash to the ideological extremism of the ethno-liberal parties - I rely on the Manifesto project (Volkens et al., 2010) for a measure of the proportion of quasi-sentences indicating the party positions on identity. In order to measure each party's ideological position on the identity dimension, I turn to the category referred to in the Manifesto Project as the "Fabric of Social Life." It is comprised of three categories: national way of life, traditional morality and multiculturalism. The overall score is the sum of the positive evaluations minus the sum of the negative evaluations of three categories. A low score on the index indicating high ideological intensity of the ethno-liberal party, is associated with tolerance, social liberalism and accommodation of minorities. A high score indicates the opposite.

To control for the incumbency effect on the radical right party's success, I include the natural log of the radical right party's vote share in the previous election as a lagged dependent variable. The second incumbency measure is an indicator of whether the 
radical right party was in the governing coalition in the previous electoral cycle. This is intended to control for advantageous access to state resources and the gains in credibility that the radical right party earned during the previous electoral cycle.

Finally, since the dataset that I have created is structured as a pooled crossnational, quasi-time series, it is necessary to account for the fact that elections are nested over time within countries. To control for the time effects due to the fact that vote shares are measured in consecutive elections, I control for the years since the first, foundational election. I estimate a set of censored models with random effects to account for the hierarchical data structure.

\section{A Statistical Model}

Electoral success is measured as the vote share of the radical right party in a given country-election-year. ${ }^{10}$ To provide a sense of the distribution, the mean vote share for the radical right parties in ninety-three elections is $6.5 \%$ for the whole distribution and $7.7 \%$ for the non-censored part. The range is between $0.07 \%$ and $50 \%$ percent. In thirteen elections, the vote share of the radical right party was below one percent, and in fourteen elections no radical right party contested the elections at all.

I include all elections in the statistical analysis regardless of the absence or presence of the radical right parties on the ballot. This is done to avoid any potential bias from disregarding the "censored cases," defined as elections in which the radical right parties do not field any candidates. To include elections with zero vote shares, I use a latent variable model for censored outcomes (Jackman \& Volpert, 1996; Golder, 2003; Swank \& Betz, 2003). The random effects model in non-linear panel data is widely preferred over the fixed effects model due to the inconsistency and bias of the maximum 
likelihood estimator. ${ }^{11}$ I modify the model outlined in Greene (2008) and Henningsen (2011) and limit the censoring structure to left side. This left censored regression model for panel data with country specific effects can be written as follows:

$$
\begin{aligned}
& y_{i t}^{*}=x_{i t}^{T} \beta+\varepsilon_{i t}=x_{i t}^{T} \beta+\mu_{i}+v_{i t} \\
& y_{i t}=a \quad \text { if } y_{i t}^{*} \leq a, \\
& y_{i}=y_{i t}^{*} \quad \text { if } y_{i t}^{*}>a
\end{aligned}
$$

The subscripts $i=1, \ldots, N$ cover the countries, while subscripts $t=1, \ldots, T_{i}$ indicate the time period, starting with 1 as the post-foundational election. $T_{i}$ is the number of years observed for the $i^{\text {th }}$ country; $\mu_{i}$ is a time-invariant country specific effect; and $v_{i t}$ is the remaining disturbance. Assuming that the country specific effects $\mu_{i}$ are independent of the covariates, we can estimate the parameters with a random effects model. Assuming further that specific country effects $\mu$ follow a normal distribution with mean 0 and variance $\sigma_{v}^{2}$, and $\mu$ and $v$ are independent, the likelihood contribution of a single country $i$ is given as follows:

$$
\mathscr{L}_{i}=\int_{-\infty}^{\infty}\left\{\prod_{t=1}^{T_{i}}\left[\Phi\left(\frac{a-x_{i t}^{\prime} \beta-\mu_{i}}{\sigma_{v}}\right)\right]^{I_{i t}^{a}}\left[\frac{1}{\sigma_{v}} \phi\left(\frac{y_{i t}-x_{i t}^{\prime} \beta-\mu_{i}}{\sigma_{v}}\right)\right]^{\left(1-I_{i t}^{a}\right)}\right\} \phi\left(\frac{\mu_{i}}{\sigma_{\mu}}\right) d \mu_{i}
$$

where $\phi($.$) and \Phi($.$) denote the probability density function and the cumulative$ distributive function, respectively, of the standard normal distribution, and $\mathrm{I}_{i}^{a}$ is the indicator function with:

$$
\begin{array}{ll}
\mathrm{I}_{i t}^{a}=0 & \text { if } y_{i t}>a \\
\mathrm{I}_{i t}^{a}=1 & \text { if } y_{i t}=a
\end{array}
$$

An important assumption of the censored model is that the underlying process that causes the party to be absent from an election is identical to the process that explains the electoral support of parties that in fact entered the race. In addition to the fourteen 
elections in which no party was present on the ballot, there were twenty-six contested elections in which radical right parties received less than 2.5 percent of the vote, and thirty-nine contested elections in which parties received less than 5 percent of the vote.

Given that many countries impose a five percent electoral threshold, this large number of elections where radical right parties could not have been expected to win a seat in the legislature leads me to believe that it is not necessary to model the selection process in which no parties appear on the ballot separately. The theory should be able to both explain cases in which parties do not contest the election as well as cases in which parties receive a negligible number of votes.

\section{Empirical Results}

I first look descriptively at the electoral success of radical right parties. Using the total number of elections as the baseline, radical right parties succeeded (i.e. were able to win at least one seat) in 43 out of 93 elections. Of these 43 electoral successes, 37 were preceded by a "coalition with one of the bilateral opposites" (Table 2). The contrapositive is also informative in 37 out of 43 elections without a radical right party success at time $t$ were not preceded by a "coalition with one of the bilateral opposites" at $t-1$.

\section{- TABLE 2 HERE -}

Table 3 further disaggregates coalitions into two groups - coalitions with ethnoliberal parties and coalitions with radical right parties - and shows that the results are robust. Using the total number of elections with "coalitions with one of the bilateral opposites" as the baseline, 37 of 50 elections with "coalitions with one of the bilateral opposites" in time $t$ resulted in the electoral success of the radical right party in the subsequent election. In 22 out of 33 elections, the electoral success of the radical right 
party was preceded by a governing coalition in which the ethno-liberal party obtained a portfolio. Radical right parties succeeded in two thirds of elections when the ethno-liberal party controlled a governmental portfolio in the previous electoral cycle.

- TABLE 3 HERE -

These descriptive statistics suggest a strong relationship between the government participation of an ethno-liberal party and the success of a radical right party and point to the plausibility of the backlash mechanism. The results also uncover a strong incumbency effect, showing that a radical right party held a portfolio in a government that preceded the electoral radical right's success in 15 out of 17 elections.

The case of Slovakia suggests the importance of holding a government portfolio for radical right mobilization. In 2002, the Hungarian ethnic party (MKP) was invited to join the governing coalition and used its power to promote minority schooling, including a new Hungarian speaking Selye János University. MKP was also granted the portfolio for regional development and used it ruthlessly to channel resources to Hungarian districts. This re-mobilized the Slovak National Party (SNS), which was rife with internal discord and had been in decline. In the 2006 election, SNS reunited and secured almost twelve percent of the vote and a partnership in the governing coalition. This granted SNS the portfolio of the Ministry of Regional Development and the ability to briskly shift resources away from Hungarian districts and towards predominantly Slovak districts. ${ }^{12}$

Turning to the multivariable statistical results, the electoral success of the ethnoliberal party in the previous electoral cycle increases the prospects for the radical right party in the subsequent electoral cycle, which is consistent with Hypothesis 1 (Table 4). Consistent with Hypothesis 2, presence of an ethno-liberal party in a governing coalition 
also increases the electoral prospects of the radical right party in the next electoral cycle. Empirical evidence for Hypothesis 3 is discussed later in the text.

The results, based on the relationship between the size of the titular majority and party support, indicate that the size of the minority is negatively related to the electoral prospect of the radical right parties, and that countries with smaller ethnic minorities are more likely to have more successful radical right parties. ${ }^{13}$ Finally, I find evidence of a strong incumbency effect for radical right parties. The electoral strength of the radical right party in the previous cycle, and to a lesser extent its presence in the previous government, predicts the radical right party's electoral success in the subsequent electoral cycle.

To explore the marginal effects of the variables, I constructed a "violin plot" (Hintze \& Nelson, 1998). It combines the advantages of a boxplot, which indicate the average effect and the uncertainty, with a kernel density plot that more effectively shows the distribution of the variable's effect. Specifically, I constructed a box plot of the marginal effect under two high probability scenarios and then added a rotated kernel density plot to each side of the box plot. The marginal effects are drawn from postestimations using as the basis the censored regression Model 2 in Table $4 .^{14}$

\section{- TABLE 4 HERE -}

Figure 1 illustrates the marginal effect of two key variables. The top panel compares the expected vote share for the radical right at time $t$ when an ethno-liberal party was included in a coalition at time $t-1$ (top right) vs. when the radical right was not included in a governing coalition (top left). The effect of being in a coalition increased the expected vote share for the radical right by a factor of roughly two, or double the share of votes. The bottom panel compares the expected vote share for the radical right at 
time $t$ (bottom left) when an ethno-liberal party received relatively few votes $\left(25^{\text {th }}\right.$ percentile) at time $t$ - 1 vs. when an ethno-liberal party received a significant share of votes ( $75^{\text {th }}$ percentile, bottom right). On average, the effect size is comparable to the coalition effect size. It roughly doubles the vote share for the radical right.

\section{- FIGURE 1 HERE -}

Spies and Franzmann (2011) show that party system polarization on cultural issues and the lack of polarization on economic issues jointly increase extremist voting. Whereas the presence of ethno-liberal parties polarizes the electorate and increases the salience on identity issues, parties can project positions on economic issues that are salient while also being centrist. Agreement among the major parties on the direction of market reforms signifies policy convergence (Frye 2002). At the same time, rapid economic policy changes will tend to increase the salience of economic issues. The analysis consistently shows that economic grievances, such as unemployment, are statistically unrelated to support for radical right parties (Table 4). ${ }^{15}$

To further explore the link between economic salience and support for radical right parties, I created a new measure of "Economic Volatility". It is based on the composite of six EBRD transition scores (EBRD 2013). A high score can be achieved either by swift reform developments or swift retraction from liberalization policies, relative to changes in previous years. The variable captures the average relative change in economic transition scores for each electoral cycle. The results in Model 3 to Model 6 (Table 4) show that high economic volatility increases support for radical right voting, controlling for unemployment and wealth. This suggests that indicators of volatility and policy uncertainty, often unrelated to objective grievances, are potentially stronger 
predictors of radical right voting than measures of economic deprivation and development (c.f. Arzheimer, 2009; Tucker, 2005).

Since not all post-communist democracies are members of the European Union (EU), and radical right parties are known for their Eurosceptic views, I inspected the effect of EU membership on party strength. While the EU membership itself is unrelated to radical right support, it mediates the effect of economic volatility on radical right voting (Model 5 in Table 4). The interaction effect indicates that the membership in the EU tempered the effect of economic volatility, which suggests that the promise of EU membership has had a calming effect on the accession countries (Kelley, 2004; Vachudova, 2008). By decreasing anxiety over the economic transition, entry into the EU slightly decreased support for the radical right.

To control for distinct features of the electoral system across countries, I use Gallagher's index of disproportionality, Rae's index of party system fractionalization and Laakso-Taagepera measure of the effective number of parties. I found a modest effect for the effective number of electoral parties (Table 5) and disproportionality in the electoral system on radical right support (Model 7 in Table 4). Consistent with a controversial finding by Arzheimer and Carter (2006), support for radical right parties mildly increases as the disproportionality increases (c.f. Givens 2005). The results from the censored regression model are unaffected by voter turnout, by urban-rural cleavage (Pop-Eleches, 2010; Tavits, 2005), by special rules that secure seats in parliament for ethnic minorities and by lower thresholds allowing ethnic parties to succeed in elections (Bernauer \& Boschler, 2009). Cross-national differences in other factors-including economic grievances, fragmentation, political accountability, legacy of inter-war radicalism are also 
unable to explain why radical parties are stronger in some countries and at some times, but weaker in others.

To ensure the model properly accommodates the censored nature of the underlying data, I used Cragg's test to address the "corner solution model" specification (Green, 2008). ${ }^{16}$ I also ran the mirror image of the model, predicting vote share for ethnoliberal parties by vote share and coalition presence of radical right parties in the previous electoral cycle, and found no effect of radical right vote share on support for ethno-liberal parties. I also tested for the robustness of ethno-liberal party coding by first excluding social liberal parties from the analysis and by recoding social liberal parties as mainstream parties. The results were robust to all of these modifications.

\section{-TABLE 5 HERE -}

I performed additional robustness checks by examining the effect of electoral system characteristics (Gallagher 2013) on support for radical right parties (Table 5). The results are remarkably robust to the inclusion of three indicators: (1) the electoral threshold, (2) the effective number of parties at the parliamentary level (seats) and (3) the effective number of parties at the electoral level (votes). The effective number of electoral parties (Model 5 and Model 6 in Table 5) shows a modestly significant and positive effect, which suggests that more diverse political systems produce stronger radical right parties. The electoral threshold and the effective number of parliamentary parties do not exhibit statistically significant effects (Table 5).

\section{- TABLE 6 HERE -}

I found a conditional support for Hypothesis 3, which predicted a positive relationship between the ideological intensity of the ethno-liberal party in the previous election and the success of the radical right parties (Table 6). ${ }^{17}$ There is no relationship 
between the absolute ideological intensity of the ethno-liberal party in the previous election and future votes for a radical right party (Model 1 in Table 6$).{ }^{18}$ It might be argued that this is hardly surprising, since the ideological intensity of the ethno-liberal party itself does not generate votes for the radical right party in the subsequent election without access to policy making and political power. Consistent with this interpretation, Hypothesis 3 is supported when the ideological intensity of the ethno-liberal party is considered jointly with the presence of the ethno-liberal party in the government.

The interaction of the ethno-liberal party coalition presence and its absolute ideological intensity is statistically significant in Model 2 (Table 6). The more accommodation sought by the ethno-liberal party that served in the governing coalition, the greater the electoral success of the radical right party in the following election. The effect of the ethno-liberal party's ideological intensity must be considered relative to the ideological intensity of the moderate proximate party. This is tested in Model 4, which includes an interaction between the presence of the ethno-liberal party in a governing coalition and its relative ideological intensity, defined as the ideological distance between the ethno-liberal party and its proximate moderate party competitor. Although the relative ideological intensity of the ethno-liberal party does not have an independent effect on the vote shares of the radical right party, its interaction with coalition presence points in the expected direction.

When an ethno-liberal party that seeks high levels of accommodation is included in a coalition, the radical right succeeded in the ensuing election. ${ }^{19}$ Table 6 shows that the absolute and relative ideological intensity of the ethno-liberal parties matters only if the 
ethno-liberal parties obtain a platform to express their views and realize their preferences in coalition governments.

I found no evidence that the positions of the mainstream parties themselves have any discernible effect on the radical right party success. I also found no effect of ideological convergence of mainstream parties and no effect of the ideological distance between the mainstream right and radical right on radical right party success. ${ }^{20}$ None of these robustness checks altered the core finding that the ethno-liberal party's coalition presence and its electoral success increase the vote shares for the radical right party in the following election. These results strongly suggest that the electoral success of radical right parties depends on polarization driven by non-proximate parties.

Focusing on the political effect of bilateral opposite parties helps to address an important policy issue - how should mainstream parties address the challenge of radical right parties? Scholars fundamentally disagree about whether the most effective strategy to keep radical parties at bay is to radicalize or to moderate. Some have suggested that support for a radical right party decreases when the proximate mainstream party radicalizes on identity issues, steals the extremist issue, and "squeezes out" the radical right. Others submit that when a proximate mainstream party radicalizes, it facilitates the rise of radical parties, since the mainstream party legitimizes the extremist agenda and facilitates outbidding on the extreme pole of the political spectrum (Adams \& SomerTopcu, 2009; Art, 2011; Bale, 2003; Cappocia, 2001; Downs, 2001; Ignazi, 1992; Jenne, 2007; Kelley, 2004; Mudde, 2007).

Although it is perhaps tempting to look for explanations of radical right party success in their immediate ideological neighborhood, these results indicate that such an 
approach may be misleading, for it risks attributing to the mainstream parties what should actually be imputed to the bilateral opposite parties. There is evidence to support the claim that both strategies can effectively shut radical right parties out of politics but may also make them martyrs of nationalist causes.

The theory and the analysis suggest that we should turn our attention towards the study of non-proximate parties (Meguid, 2005; Sartori, 1976). Ethno-liberal parties are natural and credible representatives for highly accommodative policies toward ethnic and social minorities. When moderate parties bring them on board, the political pendulum swings in their direction, but the unintended consequence is an obvious political backlash against accommodation. Radical right parties are credible agents to carry forward this reactionary agenda and benefit electorally from the success of their ideological twin. The dynamic of political backlash against the accommodation of ethno-liberal parties is a real political force, and provides significant explanatory purchase on explaining the rise and fall of the radical right across highly varied contexts.

\section{Conclusion}

This paper presents a new theory of radical right politics, and derives testable implications of the theory using new data set that covers elections in all post-communist democracies over the past twenty years. The results indicate strong support for the first two hypotheses and qualified support for the third one. The analysis shows that the electoral prospects of radical right parties improve with the electoral strength of their bilateral opposites, namely the ethno-liberal parties. They also gain substantial strength 
when the ethno-liberal party serves in the government and when the ethno-liberal party is ideologically extreme.

Although the literature has largely focused upon the role of mainstream and proximate parties, this study shows that the radical right's ideological bilateral opposite ethno-liberal parties - plays a crucial role. To a large extent, then, the rise and fall of radical right parties is a reactive political phenomenon, an electoral response to the political fortunes of their ideological twins. Parties advocating minority accommodation polarize party systems and empower radical right party appeals.

In some ways, this argument represents a return to an earlier literature on the origins of radical right parties in Western Europe. Some of the first studies recognized that the sudden rise in radical right-wing politics in the 1980s was initially a form of a backlash against the new political forces representing voters with post-material, socially liberal values and green parties (Ignazi, 1992; Kitschelt \& McGann, 1995; von Beyme, 1988). These early insights have been largely lost in the ensuing debate, which focused upon the profile of radical right voters, the institutional and structural determinants of radical right support and on the dynamics of competition between the mainstream parties.

Can the argument advanced here travel beyond Eastern Europe? Only further analysis will show for sure, but the answer may lie in re-assessing a well-established consociational theory (Lijphart, 1984). The political impact of power-sharing institutions might be mitigated by the size of the quarrelling groups. Netherlands initially avoided a large-scale conflict between its large pillars due to the accommodation. Yet built in mechanisms to placate minorities might have fueled radical right parties in countries such 
as Austria, Bosnia, Lebanon and Switzerland, where discontent has been generated by disproportionate accommodation afforded to small minorities.

In Eastern Europe, parties quibble over language policies. Elsewhere, politicians argue over head-coverings and housing subsidies for ethnic minorities. The vehicles of accommodation differ with contexts. Yet the argument that accommodation of minorities polarizes the electorate, increases the salience of non-economic issues and can create a political backlash may be unfortunately universal. 


\section{References:}

Adams, James; Clark, Michael; Ezrow, Lawrence; Glasgow, Garrett. (2006). Are niche parties fundamentally different from mainstream parties? The causes and the electoral consequences of Western European parties“ policy shifts, 1976-1998. American Journal of Political Science, 50, 513-529.

Adams, James, and Zeynep Somer-Topcu. (2009). Do parties adjust their policies in response to rival parties' policy shifts? Spatial theory and the dynamics of party competition in twenty-five democracies. British Journal of Political Science, 39, 825846.

Art, David. (2011). Inside the radical right: The development of anti-immigrant parties in Western Europe. Cambridge, UK: Cambridge University Press.

Arzheimer, Kai. (2009). Contextual factors and the extreme right vote in Western Europe, 1980-2002. American Journal of Political Science, 53, 259-275.

Arzheimer, Kai and Elisabeth Carter. 2006. "Political Opportunity Structures and RightWing Extremist Party Success.” European Journal of Political Research 45(3): 419443.

Bale, Tim. (2003). Cinderella and her ugly sisters: The mainstream and extreme right in Europe's bipolarising party systems. West European Politics, 26, 67-90.

Benoit, Kenneth and Michael Laver. (2006). Party policy in modern democracies. London, UK: Routledge.

Bernauer, Julian and Daniel Bochsler. (2009). Electoral entry and success of ethnic minority parties in Central and Eastern Europe: A hierarchical selection model. Manuscript. 
Betz, Hans-Georg. (1994). Radical right-wing populism in Western Europe. Basingstoke: Macmillan.

Bunce, Valerie. (1999). Subversive institutions. Cambridge, UK: Cambridge U. Press.

Bustikova, Lenka and Herbert Kitschelt. (2009). The radical right in post-communist Europe. Comparative perspectives on legacies and party competition. Communist and Post-Communist Studies, 42, 459-483.

Capoccia, Giovanni. (2001). Defending democracy: Reactions to political extremism in inter-war Europe. European Journal of Political Research, 39, 431-460.

Carter, Elisabeth. (2005). The Extreme right in Western Europe: Success or failure? Manchester, UK: Manchester University Press.

Chandra, Kanchan. (2004). Why ethnic parties succeed. Cambridge, UK: Cambridge Press.

Colomer, Josep M. and Riccardo Puglisi. (2005). Cleavages, issues and parties: A critical overview of the literature. European Political Science, 4, 502-520.

Dancygier, Rafaela. (2010). Immigration and conflict in Europe. Cambridge, UK: Cambridge University Press.

Downs, William M. (2001). Pariahs in their midst: Belgian and Norwegian parties react to extremist threats. West European Politics, 24, 23-42.

Eatwell, Roger. (2003). Ten theories of the extreme right, in Peter Merkl and Leonard Weinberg, eds., Right-Wing Extremism in the Twenty First Century. Portland, Oregon: Frank Cass.

EBRD. 2013 Transition Indicators.

http://www.ebrd.com/pages/research/economics/data/macro.shtml 
Efron, Bradley and Tibshirani, Robert. (1993). An introduction to the bootstrap. Boca Raton, FL: Chapman \& Hall/CRC.

Ekiert, Grzegorz. (2006.) L'instabilité du système partisan. Le maillon faible de la consolidation démocratique en Pologne. Pouvoirs 118, 37-58.

Frye, Timothy. (2002). The perils of polarization: Economic performance in the postcommunist World. World Politics, 54, 308-37.

Givens, Terri. (2005). Voting Radical Right in Western Europe. Cambridge: Cambridge University Press.

Givens, Terri. (2004). The radical right gender gap. Comparative Political Studies 37, 3054.

Golder, Matt. (2003). Explaining variation in the success of extreme right parties in Western Europe. Comparative Political Studies 36, 32-66.

Golder, Nadenichek Sona and Conrad, Courtenay Ryals. (2010). Measuring government duration and stability in Central Eastern European democracies. European Journal of Political Research 49, 119-150.

Greene, William C. (2008). Econometric analysis, 6th edition. New York: Prentice Hall Greskovits, Béla. (2007). Economic woes and political disaffection. Journal of Democracy, 18, 40-46.

Grzymala-Busse, Anna. (2002). Redeeming the communist past. Cambridge, UK: Cambridge University Press.

--- 2001. "Coalition formation and the regime divide in new democracies: East central Europe." Comparative Politics, 34, 85-104. 
Hintze, Jerry and Nelson Ray. (1998). Violin plots: a box plot-density trace synergism. The American Statistician, 52, 181-4.

Held, Joseph, ed. (1996). Populism in eastern Europe. Racism, nationalism, and society. Boulder CO: East European Monographs.

Hockenos, Paul. (1993). Free to Hate: The rise of the right in post-communist Eastern Europe. New York: Routledge.

Horowitz, Donald. (1985). Ethnic groups in conflict. University of California Press.

Ignazi, Piero. (1992). The silent counter-revolution. Hypotheses on the emergence of extreme right-wing parties in Europe. European Journal of Political Research, 22, 334.

Ishiyama, John, T. (2009). Historical legacies and the size of the red brown vote in post-c ommunist politics. Communist and Post-Communist Studies, 42, 485-504.

Ishiyama, John, T. (1997). The sickle or the rose? Comparative Political Studies, 30, 299-330.

Ivarsflaten, Elisabeth. (2008). What unites right-wing populists in Western Europe? Reexamining grievance mobilization models in seven successful cases. Comparative Political Studies, 41, 3-23.

Jackman, Robert W and Karin Volpert. (1996). Conditions favouring parties of the extreme right in western Europe. British Journal of Political Science, 26, 501-521.

Jenne, Erin. (2007). Ethnic bargaining: The paradox of minority empowerment. Ithaca, NY: Cornell University Press.

Kedar, Orit. (2005). When moderate voters prefer extreme parties: Policy balancing in parliamentary elections. American Political Science Review, 99, 185-199. 
Kelley, Judith. (2004). Ethnic politics in Europe. The power of norms and incentives. Princeton University Press.

Kitschelt, Herbert. (2007). Growth and persistence of the radical right in postindustrial democracies: Advances and challenges in comparative research. West European Politics, 30, 1176-1206.

Kitschelt et al. (2008). Democratic accountability and linkages project. Duke University.

Kitschelt, Herbert and Anthony McGann. (1995). The radical right in Western Europe: A comparative analysis. Ann Arbor: University of Michigan Press.

Kopecky, Petr and Mudde, Cas, eds. (2003). Uncivil society? Contentious politics in post-communist Europe. London: Routledge.

Laver, Michael. (1998). Models of government formation. Annual Review of Political Science 1, 1-25.

Laver, Michael and Norman Schofield. (1990). Multiparty government: The politics of coalition in Europe. Ann Arbor, MI: University of Michigan Press.

Lijphart, Arend. (1984). Democracies: Patterns of majoritarian and consensus democracies in twenty-one countries. New Haven: Yale University Press.

Geertje Lucassen and Marcel Lubbers (2012). Who fears what? Explaining far-rightwing preference in Europe by distinguishing perceived cultural and economic ethnic threats. Comparative Political Studies, 45, 547-574.

Meguid, Bonnie. (2008). Party competition between unequals. Cambridge, UK: Cambridge University Press.

Meguid, Bonnie. (2005). Competition between unequals: The role of mainstream party strategy in niche party success. American Political Science Review, 99, 347-59. 
Minkenberg, Michael. (2002). The radical right in post-socialist central and Eastern Europe: Comparative observations and interpretations. East European Politics and Society, 16, 335-62.

Mudde, Cas. (2007). Populist radical right parties in Europe. Cambridge, UK: Cambridge University Press.

--- (2005). Racist extremism in central and Eastern Europe. London: Routledge.

Norris, Pippa. (2005). Radical Right. Voters and parties in the electoral market. Cambridge, UK: Cambridge University Press.

O'Dwyer, Conor and Katrina Schwartz. (2010). Minority rights after EU enlargement: A comparison of antigay politics in Poland and Latvia. Comparative European Politics, 8, 220-243.

Olzak, Susan. (1992). The dynamic of ethnic competition and conflict. Stanford University Press.

Ost, David. (2005). The defeat of solidarity. Anger and politics in post-communist Europe. Cornell University Press.

Petersen, Roger. (2002). Understanding ethnic violence. Cambridge, UK: Cambridge University Press.

Pop-Eleches, Grigore. (2010). Throwing out the bums: Protest voting and unorthodox parties after communism. World Politics, 62, 221-260.

Ramet, Sabrina, ed. (1999). The radical right in central and Eastern Europe since 1989. The Pennsylvania State University Press.

Riker, William. (1962). The theory of political coalitions. New Haven: Yale University Press. 
Sartori, Giovanni. (1976). Parties and party systems. Cambridge, UK: Cambridge University Press.

Shafir, Michael. (2002). Between denial and 'comparative trivialization.' Holocaust negotiations in post-communist east central Europe, Analysis of Current Trends in Antisemitism 19.

Smith, Jason Matthew. (2010). Does crime pay? Issue ownership, political opportunity, and the populist right in western Europe. Comparative Political Studies, 43, 1471-1498.

Spies, Dennis and Simon T. Franzmann. (2011). A Two-Dimensional Approach to the Political Opportunity Structure of Extreme Right Parties in Western Europe. West European Politics, 34, 1044-1069.

Swank, Duane and Hans-Georg Betz. (2003). Globalization, the welfare state and rightwing populism in western Europe. Socio-Economic Review, 1, 215-45.

Tavits, Margit. (2005). The development of stable party support: Electoral dynamics in post-communist Europe. American Journal of Political Science, 49, 283-98.

Thompson, Michael, Richard Ellis and Aaron Wildavsky. (1990). Cultural theory. Westview Press, Boulder, San Franciso \& Oxford.

Tucker, Joshua. (2005.) Red, brown, and regional economic voting: Russia, Poland, Hungary, Slovakia, and the Czech Republic from 1990-99. MPSA, Chicago, IL.

Vachudova, Milada Anna. (2008). Tempered by the EU? Political parties and party systems before and after accession. Journal of European Public Policy, 15, 861-879.

Van der Brug, Wouter, Meindert Fennema, and Jean Tillie. (2005). Why some antiimmigrant parties fail and others succeed: A two-step model of aggregate electoral support. Comparative Political Studies, 38, 537-573. 
Volkens, Andrea et al. (2010). The Manifesto Data Collection. Berlin: Wissenschaftszentrum Berlin für Sozialforschung.

Von Beyme, Klaus. (1988). Right-wing extremism in post-war Europe. West European Politics, 11, 1-18.

Wilkinson, Steven. (2004). Votes and violence. Electoral competition and ethnic riots in India. Cambridge, UK: University Press.

Wittenberg, Jason and Jeffrey S. Kopstein. (2011). Deadly communities: Local political milieus and the persecution of Jews in occupied Poland. Comparative Political Studies, 44, 259-283. 
Table 1: Combined vote shares for Radical Right Parties since the founding elections

\begin{tabular}{lccccccc} 
& \multicolumn{7}{c}{ Elections } \\
& $1^{\text {st }}$ & $2^{\text {nd }}$ & $3^{\text {rd }}$ & $4^{\text {th }}$ & $5^{\text {th }}$ & $6^{\text {th }}$ & $7^{\text {th }}$ \\
\hline Albania & 4.97 & 2.30 & 2.40 & 0.60 & 0.34 & & \\
Bulgaria & 1.13 & 0.54 & 0.18 & 0.07 & 8.14 & 9.36 & \\
Croatia & 50.00 & 47.51 & 31.85 & 6.37 & 3.50 & 3.00 & \\
Czech Rep & 5.98 & 8.01 & 3.09 & 1.08 & 0.17 & 1.14 & \\
Estonia & 11.50 & 16.10 & 8.40 & 1.70 & 0.40 & & \\
Hungary & 1.59 & 5.47 & 4.37 & 2.20 & 16.67 & & \\
Latvia & 11.99 & 14.37 & 5.39 & 6.94 & 7.67 & & \\
Lithuania & 4.01 & 2.77 & 0.28 & 1.75 & 0.63 & & \\
Macedonia & 0.00 & 0.00 & 6.10 & 0.24 & 2.51 & & \\
Moldova & 0.00 & 0.00 & 0.00 & 0.00 & 0.00 & 0.00 & \\
Montenegro & 0.00 & 0.00 & 0.00 & 0.00 & 0.00 & & \\
Poland & 2.85 & 5.63 & 7.87 & 8.00 & 1.30 & 0.07 & \\
Romania & 8.82 & 19.48 & 15.12 & 5.42 & 13.98 & & \\
Serbia Montenegro, FRY & 8.60 & 35.27 & 28.59 & 29.46 & 4.63 & & \\
Slovakia & 7.93 & 5.40 & 9.07 & 6.98 & 11.73 & 5.07 & 4.55 \\
Slovenia & 3.22 & 4.39 & 6.27 & 5.40 & 1.80 & & \\
Ukraine & 1.25 & 1.00 & 0.00 & 0.36 & 0.76 & 10.45 &
\end{tabular}


Table 2: The Electoral Success of radical right parties in $t$ by a "coalition with one of the bilateral (B-L) opposites" in $t-1$

\begin{tabular}{lccc} 
& $\begin{array}{c}\text { Coalition with B-L } \\
\text { opposite } \\
\text { in } \boldsymbol{t} \text { - } 1\end{array}$ & $\begin{array}{c}\text { No coalition with B-L } \\
\text { opposite } \\
\text { in } \boldsymbol{t} \text { - } 1\end{array}$ & Totals \\
\hline Electoral success of RR in $\boldsymbol{t}$ & 37 & 6 & 43 \\
Electoral failure of RR in $\boldsymbol{t}$ & 13 & 37 & 50 \\
\hline & 50 & 43 & 93
\end{tabular}

Electoral success of radical right party in $t$, (number of parliamentary seats $>1$ )

Electoral failure of the radical right party in $t$, (no parliamentary seats gained in $t$ )

Presence of a "coalition with one of the bilateral opposites" in previous elections $(t-1)$

No "coalition with one of the bilateral opposites" in the previous electoral cycle $(t-1)$ 
Table 3: The Electoral Success of radical right parties in $t$ by coalition type in $t-1$

\begin{tabular}{lccc} 
& $\begin{array}{c}\text { Ethno-liberal party } \\
\text { in a coalition } \\
\text { in } \boldsymbol{t}-\boldsymbol{1}\end{array}$ & $\begin{array}{c}\text { Radical right party } \\
\text { in a coalition } \\
\text { in } \boldsymbol{t}-\mathbf{1}\end{array}$ & \\
\hline Electoral success of RR in $\boldsymbol{t}$ & $\mathbf{2 2}$ & 15 & Totals \\
\hline Electoral failure of RR in $\boldsymbol{t}$ & 11 & 2 & 37 \\
\hline & 33 & 17 & 13 \\
\hline
\end{tabular}

Electoral success of radical right party in $t$, (number of parliamentary seats $>1$ )

Electoral failure (no parliamentary seats for radical right party in $t$ ) 
Table 4: Determinants of the electoral support for the radical right parties Censored regression with random effects, DV: log of total vote shares for the radical right parties

\begin{tabular}{|c|c|c|c|c|c|c|c|c|}
\hline & (M1) & (M2) & (M3) & (M4) & (M5) & (M6) & (M7) & (M8) \\
\hline $\begin{array}{l}\text { Ethno-liberal party in coalition ( } \mathrm{t}-1) \\
\text { (1=participated) }\end{array}$ & $\begin{array}{l}.522^{* *} \\
(.204)\end{array}$ & $\begin{array}{l}.504^{* *} \\
(.204)\end{array}$ & $\begin{array}{l}.520^{* * *} \\
(.197)\end{array}$ & $\begin{array}{l}.553^{* * *} \\
(.195)\end{array}$ & $\begin{array}{l}.499^{* *} \\
(.206)\end{array}$ & $\begin{array}{l}.418^{* *} \\
(.209)\end{array}$ & $\begin{array}{l}.519^{* * *} \\
(.201)\end{array}$ & $\begin{array}{l}.472^{* *} \\
(.200)\end{array}$ \\
\hline Ethno-liberal party vote share (t-1) & $\begin{array}{l}.249^{* * *} \\
(.087)\end{array}$ & $\begin{array}{l}.230^{* * *} \\
(.082)\end{array}$ & $\begin{array}{l}.246^{* * *} \\
(.084)\end{array}$ & $\begin{array}{l}.263^{* * *} \\
(.090)\end{array}$ & $\begin{array}{l}.268^{* * *} \\
(.087)\end{array}$ & $\begin{array}{l}.191^{* *} \\
(.083)\end{array}$ & $\begin{array}{l}.221^{* * *} \\
(.078)\end{array}$ & $\begin{array}{l}.223^{* * *} \\
(.077)\end{array}$ \\
\hline $\begin{array}{l}\text { Radical right party in coalition }(t-1) \\
(1=\text { participated) }\end{array}$ & $\begin{array}{l}.665^{* *} \\
(.273)\end{array}$ & $\begin{array}{l}.796^{* * *} \\
(.266)\end{array}$ & $\begin{array}{l}.567^{* *} \\
(.265)\end{array}$ & $\begin{array}{l}.616^{* *} \\
(.261)\end{array}$ & $\begin{array}{l}.729^{* * *} \\
(.256)\end{array}$ & $\begin{array}{l}.483^{*} \\
(.282)\end{array}$ & $\begin{array}{l}.535^{* *} \\
(.269)\end{array}$ & $\begin{array}{l}.513^{*} \\
(.273)\end{array}$ \\
\hline Radical right party vote share (t-1) & $\begin{array}{l}.603^{* * *} \\
(.125)\end{array}$ & $\begin{array}{l}.569^{* * *} \\
(.108)\end{array}$ & $\begin{array}{l}.634^{* * *} \\
(.120)\end{array}$ & $\begin{array}{l}.606^{* * *} \\
(.129)\end{array}$ & $\begin{array}{l}.597^{* * *} \\
(.109)\end{array}$ & $\begin{array}{l}.691^{* * *} \\
(.098)\end{array}$ & $\begin{array}{l}.730^{* * *} \\
(.092)\end{array}$ & $\begin{array}{l}.714^{* * *} \\
(.095)\end{array}$ \\
\hline Size of the titular majority & & $\begin{array}{l}1.274^{* *} \\
(.527)\end{array}$ & & & $\begin{array}{l}1.180^{* *} \\
(.510)\end{array}$ & & & $\begin{array}{l}.598 \\
(.541)\end{array}$ \\
\hline Economic Volatility (elect. cycle) & & & $\begin{array}{l}.0579^{* *} \\
(.026)\end{array}$ & $\begin{array}{l}.147^{* * *} \\
(.053)\end{array}$ & $\begin{array}{l}.148^{* *} \\
(.060)\end{array}$ & $\begin{array}{l}.0672^{* *} \\
(.029)\end{array}$ & & $\begin{array}{l}.0474^{*} \\
(.027)\end{array}$ \\
\hline EU membership (1=member) & & & & $\begin{array}{l}.247 \\
(.248)\end{array}$ & $\begin{array}{l}.122 \\
(.215)\end{array}$ & & & \\
\hline Interaction: EU * Econ. Volatility & & & & $\begin{array}{l}-.116^{*} \\
(.060)\end{array}$ & $\begin{array}{l}-.114^{*} \\
(.060)\end{array}$ & & & \\
\hline Years since the $1^{\text {st }}$ election & & & & & $\begin{array}{l}.00435 \\
(.017)\end{array}$ & & & \\
\hline Wealth - GDP/PC (t-1) & & & & & & $\begin{array}{l}.0862 \\
(.176)\end{array}$ & & \\
\hline Unemployment (t-1) & & & & & & $\begin{array}{l}-.008 \\
(.010)\end{array}$ & & \\
\hline Disproportionality & & & & & & & $\begin{array}{l}.026^{*} \\
(.016)\end{array}$ & $\begin{array}{l}.014 \\
(.017)\end{array}$ \\
\hline Constant & $\begin{array}{l}-.202 \\
(.192)\end{array}$ & $\begin{array}{l}-5.741^{* *} \\
(2.312)\end{array}$ & $\begin{array}{l}-.341^{*} \\
(.197)\end{array}$ & $\begin{array}{l}-.531^{* *} \\
(.235)\end{array}$ & $\begin{array}{l}-5.689^{* *} \\
(2.232)\end{array}$ & $\begin{array}{l}-.985 \\
(1.575)\end{array}$ & $\begin{array}{l}-.475^{*} \\
(.244)\end{array}$ & $\begin{array}{l}-3.092 \\
(2.323)\end{array}$ \\
\hline Sigma (u) & $\begin{array}{l}.234 \\
(.177)\end{array}$ & $\begin{array}{l}.129 \\
(.217)\end{array}$ & $\begin{array}{l}.211 \\
(.176)\end{array}$ & $\begin{array}{l}.259 \\
(.171)\end{array}$ & $\begin{array}{l}.138 \\
(.204)\end{array}$ & $\begin{array}{l}2.72 \mathrm{e}-16 \\
(.182)\end{array}$ & $\begin{array}{l}2.02 \mathrm{e}-16 \\
(.176)\end{array}$ & $\begin{array}{l}2.19 \mathrm{e}-17 \\
(.152)\end{array}$ \\
\hline Sigma (e) & $\begin{array}{l}.662^{* * *} \\
(.061)\end{array}$ & $\begin{array}{l}.664^{* * *} \\
(.061)\end{array}$ & $\begin{array}{l}.645^{* * *} \\
(.060)\end{array}$ & $\begin{array}{l}.622^{* * *} \\
(.058)\end{array}$ & $\begin{array}{l}.630^{* * *} \\
(.059)\end{array}$ & $\begin{array}{l}.667^{* * *} \\
(.058)\end{array}$ & $\begin{array}{l}.644^{* * *} \\
(.057)\end{array}$ & $\begin{array}{l}.631^{* * *} \\
(.056)\end{array}$ \\
\hline Number of elections & 93 & 93 & 93 & 93 & 93 & 80 & 76 & 76 \\
\hline Number of countries & 17 & 17 & 17 & 17 & 17 & 17 & 17 & 17 \\
\hline Log Likelihood & -91.93 & -88.61 & -89.54 & -87.75 & -84.84 & -76.52 & -71.04 & -68.88 \\
\hline Chi2 & 107.5 & 143.5 & 118.7 & 114.7 & 157.5 & 157.2 & 163.1 & 168.7 \\
\hline AIC & 197.9 & 193.2 & 195.1 & 195.5 & 193.7 & 173.0 & 158.1 & 157.8 \\
\hline Censored Observations & 14 & 14 & 14 & 14 & 14 & 12 & 11 & 11 \\
\hline Uncensored Observations & 79 & 79 & 79 & 79 & 79 & 68 & 65 & 65 \\
\hline
\end{tabular}


Table 5: Determinants of the electoral support for the radical right parties Censored regression with random effects, DV: $\log$ of total vote shares for the radical right parties Robustness Checks for the Effect of Electoral Systems

\begin{tabular}{|c|c|c|c|c|c|c|c|}
\hline & (M1) & (M2) & (M3) & (M4) & (M5) & (M6) & (M7) \\
\hline Ethno-liberal party in coalition (t-1) & $.463^{* *}$ & $.478^{* *}$ & $.520^{* *}$ & $.495^{* *}$ & $.573^{* * *}$ & $.581^{* * *}$ & $.484^{* *}$ \\
\hline (1=participated) & $(.189)$ & $(.187)$ & $(.203)$ & $(.205)$ & $(.177)$ & $(.178)$ & $(.203)$ \\
\hline Ethno-liberal party vote share (t-1) & $\begin{array}{l}.222^{* * *} \\
(.078)\end{array}$ & $\begin{array}{l}.223^{* * *} \\
(.078)\end{array}$ & $\begin{array}{l}.167^{* *} \\
(.079)\end{array}$ & $\begin{array}{l}.183^{* *} \\
(.081)\end{array}$ & $\begin{array}{l}.231^{* * *} \\
(.074)\end{array}$ & $\begin{array}{l}.228^{* * *} \\
(.074)\end{array}$ & $\begin{array}{l}.227^{* * *} \\
(.079)\end{array}$ \\
\hline $\begin{array}{l}\text { Radical right party in coalition (t-1) } \\
(1=\text { participated) }\end{array}$ & $\begin{array}{l}.594^{* *} \\
(.256)\end{array}$ & $\begin{array}{l}.778^{* * *} \\
(.261)\end{array}$ & $\begin{array}{l}.551^{* *} \\
(.255)\end{array}$ & $\begin{array}{l}.614^{* *} \\
(.267)\end{array}$ & $\begin{array}{l}.534^{* *} \\
(.232)\end{array}$ & $\begin{array}{l}.659^{* * *} \\
(.242)\end{array}$ & $\begin{array}{l}.597^{* *} \\
(.273)\end{array}$ \\
\hline Radical right party vote share (t-1) & $\begin{array}{l}.672^{* * *} \\
(.087)\end{array}$ & $\begin{array}{l}.589^{* * *} \\
(.091)\end{array}$ & $\begin{array}{l}.574^{* * *} \\
(.093)\end{array}$ & $\begin{array}{l}.564^{* * *} \\
(.094)\end{array}$ & $\begin{array}{l}.667^{* * *} \\
(.082)\end{array}$ & $\begin{array}{l}.623^{* * *} \\
(.086)\end{array}$ & $\begin{array}{l}.691^{* * *} \\
(.096)\end{array}$ \\
\hline Electoral threshold & $\begin{array}{l}-.086 \\
(.099)\end{array}$ & $\begin{array}{l}-.015 \\
(.101)\end{array}$ & & & & & $\begin{array}{l}.079 \\
(.104)\end{array}$ \\
\hline Size of the titular majority & & $\begin{array}{l}1.206^{* *} \\
(.489)\end{array}$ & & $\begin{array}{l}.513 \\
(.637)\end{array}$ & & $\begin{array}{l}.746^{*} \\
(.450)\end{array}$ & $\begin{array}{l}.693 \\
(.558)\end{array}$ \\
\hline $\begin{array}{l}\text { Effective number of parties } \\
\text { (seats) }\end{array}$ & & & $\begin{array}{l}.027 \\
(.033)\end{array}$ & $\begin{array}{l}.037 \\
(.035)\end{array}$ & & & \\
\hline $\begin{array}{l}\text { Effective number of parties } \\
\text { (votes) }\end{array}$ & & & & & $\begin{array}{l}.078^{*} \\
(.043)\end{array}$ & $\begin{array}{l}.084^{*} \\
(.043)\end{array}$ & \\
\hline Disproportionality & & & & & & & $\begin{array}{l}.023 \\
(.017)\end{array}$ \\
\hline Constant & $\begin{array}{l}.177 \\
(.477)\end{array}$ & $\begin{array}{l}-5.374^{* *} \\
(2.301)\end{array}$ & $\begin{array}{l}-.0283 \\
(.240)\end{array}$ & $\begin{array}{l}-2.357 \\
(2.906)\end{array}$ & $\begin{array}{l}-.700^{* * *} \\
(.257)\end{array}$ & $\begin{array}{l}-3.968^{* *} \\
(2.005)\end{array}$ & $\begin{array}{l}-3.815 \\
(2.540)\end{array}$ \\
\hline Sigma (u) & $\begin{array}{l}.213 \\
(.190)\end{array}$ & $\begin{array}{l}.126 \\
(.224)\end{array}$ & $\begin{array}{l}1.90 \mathrm{e}-17 \\
(.121)\end{array}$ & $\begin{array}{l}3.34 \mathrm{e}-17 \\
(.120)\end{array}$ & $\begin{array}{l}.179 \\
(.147)\end{array}$ & $\begin{array}{l}.171 \\
(.148)\end{array}$ & $\begin{array}{l}1.90 \mathrm{e}-16 \\
(.166)\end{array}$ \\
\hline Sigma (e) & $\begin{array}{l}.688^{* * *} \\
(.056)\end{array}$ & $\begin{array}{l}.674^{* * *} \\
(.054)\end{array}$ & $\begin{array}{l}.616^{* * *} \\
(.056)\end{array}$ & $\begin{array}{l}.615^{* * *} \\
(.056)\end{array}$ & $\begin{array}{l}.602^{* * *} \\
(.052)\end{array}$ & $\begin{array}{l}.599^{* * *} \\
(.051)\end{array}$ & $\begin{array}{l}.640^{* * *} \\
(.057)\end{array}$ \\
\hline Number of elections & 93 & 93 & 68 & 68 & 83 & 83 & 76 \\
\hline Number of countries & 17 & 17 & 15 & 15 & 17 & 17 & 17 \\
\hline Log Likelihood & -91.91 & -88.65 & -63.21 & -62.89 & -71.78 & -70.33 & -70.10 \\
\hline Chi2 & 163.4 & 166.6 & 116.5 & 116.7 & 181.9 & 178.9 & 162.6 \\
\hline AIC & 197.8 & 193.3 & 142.4 & 143.8 & 157.6 & 156.7 & 160.2 \\
\hline Censored Observations & 14 & 14 & 6 & 6 & 13 & 13 & 11 \\
\hline Uncensored Observations & 79 & 79 & 62 & 62 & 70 & 70 & 65 \\
\hline
\end{tabular}


Table 6: Determinants of the electoral support for the radical right parties

Panel regression with random effects, DV: $\log$ of total vote shares for the radical right parties

\begin{tabular}{|c|c|c|c|c|c|c|}
\hline & (M1) & (M2) & (M3) & (M4) & (M5) & (M6) \\
\hline $\begin{array}{l}\text { Ethno-liberal party in coalition (t-1) } \\
\text { (1=participated) }\end{array}$ & $\begin{array}{l}.740^{* * *} \\
(.224)\end{array}$ & $\begin{array}{l}.599^{* * *} \\
(.222)\end{array}$ & $\begin{array}{l}.628^{* * * *} \\
(.211)\end{array}$ & $\begin{array}{l}.432^{*} \\
(.224)\end{array}$ & $\begin{array}{l}.558^{* *} \\
(.235)\end{array}$ & $\begin{array}{l}.406^{*} \\
(.234)\end{array}$ \\
\hline Ethno-liberal party vote share (t-1) & $\begin{array}{l}.172 \\
(.122)\end{array}$ & $\begin{array}{l}.219^{*} \\
(.115)\end{array}$ & $\begin{array}{l}.203^{*} \\
(.111)\end{array}$ & $\begin{array}{l}.243^{* *} \\
(.108)\end{array}$ & $\begin{array}{l}.228^{*} \\
(.117)\end{array}$ & $\begin{array}{l}.248^{* *} \\
(.110)\end{array}$ \\
\hline $\begin{array}{l}\text { Radical right party in coalition (t-1) } \\
\text { (1=participated) }\end{array}$ & $\begin{array}{l}.500 \\
(.373)\end{array}$ & $\begin{array}{l}.485 \\
(.310)\end{array}$ & $\begin{array}{l}.434 \\
(.315)\end{array}$ & $\begin{array}{l}.449 \\
(.301)\end{array}$ & $\begin{array}{l}.454 \\
(.317)\end{array}$ & $\begin{array}{l}.433 \\
(.307)\end{array}$ \\
\hline Radical right party vote share (t-1) & $\begin{array}{l}.666^{* * *} \\
(.132)\end{array}$ & $\begin{array}{l}.733^{* * *} \\
(.128)\end{array}$ & $\begin{array}{l}.741^{* * *} \\
(.124)\end{array}$ & $\begin{array}{l}.772^{* * *} \\
(.120)\end{array}$ & $\begin{array}{l}.737^{* * *} \\
(.129)\end{array}$ & $\begin{array}{l}.774^{* * *} \\
(.121)\end{array}$ \\
\hline Years since the $1^{\text {st }}$ election & $\begin{array}{l}-.025 \\
(.023)\end{array}$ & $\begin{array}{l}-.034 \\
(.022)\end{array}$ & $\begin{array}{l}-.035^{*} \\
(.021)\end{array}$ & $\begin{array}{l}-.050^{* *} \\
(.021)\end{array}$ & $\begin{array}{l}-.024 \\
(.027)\end{array}$ & $\begin{array}{l}-.043 \\
(.027)\end{array}$ \\
\hline Size of the titular majority & $\begin{array}{l}-.294 \\
(.805)\end{array}$ & & & & & \\
\hline Ethno-liberal party ideology, abs (t-1) & $\begin{array}{l}-.025 \\
(.026)\end{array}$ & $\begin{array}{l}-.002 \\
(.026)\end{array}$ & & & $\begin{array}{l}.004 \\
(.028)\end{array}$ & \\
\hline $\begin{array}{l}\text { Interaction: Ethno-liberal p. in coal. * } \\
\text { Ethno-liberal party ideology, absolute }\end{array}$ & & $\begin{array}{l}-.103^{*} \\
(.054)\end{array}$ & & & $\begin{array}{l}-.105^{*} \\
(.055)\end{array}$ & \\
\hline $\begin{array}{l}\text { Ethno-liberal party ideology, rel. (t-1) } \\
\text { (Distance from proximate competitor) }\end{array}$ & & & $\begin{array}{l}.021 \\
(.025)\end{array}$ & $\begin{array}{l}-.008 \\
(.028)\end{array}$ & & $\begin{array}{l}-.011 \\
(.029)\end{array}$ \\
\hline $\begin{array}{l}\text { Interaction: Ethno-liberal p. in coal. * } \\
\text { Ethno-liberal party ideology, relative }\end{array}$ & & & & $\begin{array}{l}.107^{* *} \\
(.053)\end{array}$ & & $\begin{array}{l}.107^{* *} \\
(.054)\end{array}$ \\
\hline Economic Volatility (elect. cycle) & & & & $\begin{array}{l}.064 \\
(.107)\end{array}$ & $\begin{array}{l}.044 \\
(.099)\end{array}$ & \\
\hline Constant & $\begin{array}{l}1.293 \\
(3.635)\end{array}$ & $\begin{array}{l}-.054 \\
(.424)\end{array}$ & $\begin{array}{l}-.074 \\
(.414)\end{array}$ & $\begin{array}{l}.060 \\
(.401)\end{array}$ & $\begin{array}{l}-.246 \\
(.536)\end{array}$ & $\begin{array}{l}-.076 \\
(.508)\end{array}$ \\
\hline Sigma (e) & .66 & .66 & .60 & .57 & .67 & .59 \\
\hline Number of elections & 39 & 39 & 38 & 38 & 39 & 38 \\
\hline Number of countries & 13 & 13 & 13 & 13 & 13 & 13 \\
\hline Chi2 & 65.68 & 76.55 & 81.08 & 93.01 & 75.32 & 90.72 \\
\hline $\mathbf{R}^{\wedge} \mathbf{2}$ & .68 & .71 & .72 & .76 & .72 & .76 \\
\hline
\end{tabular}



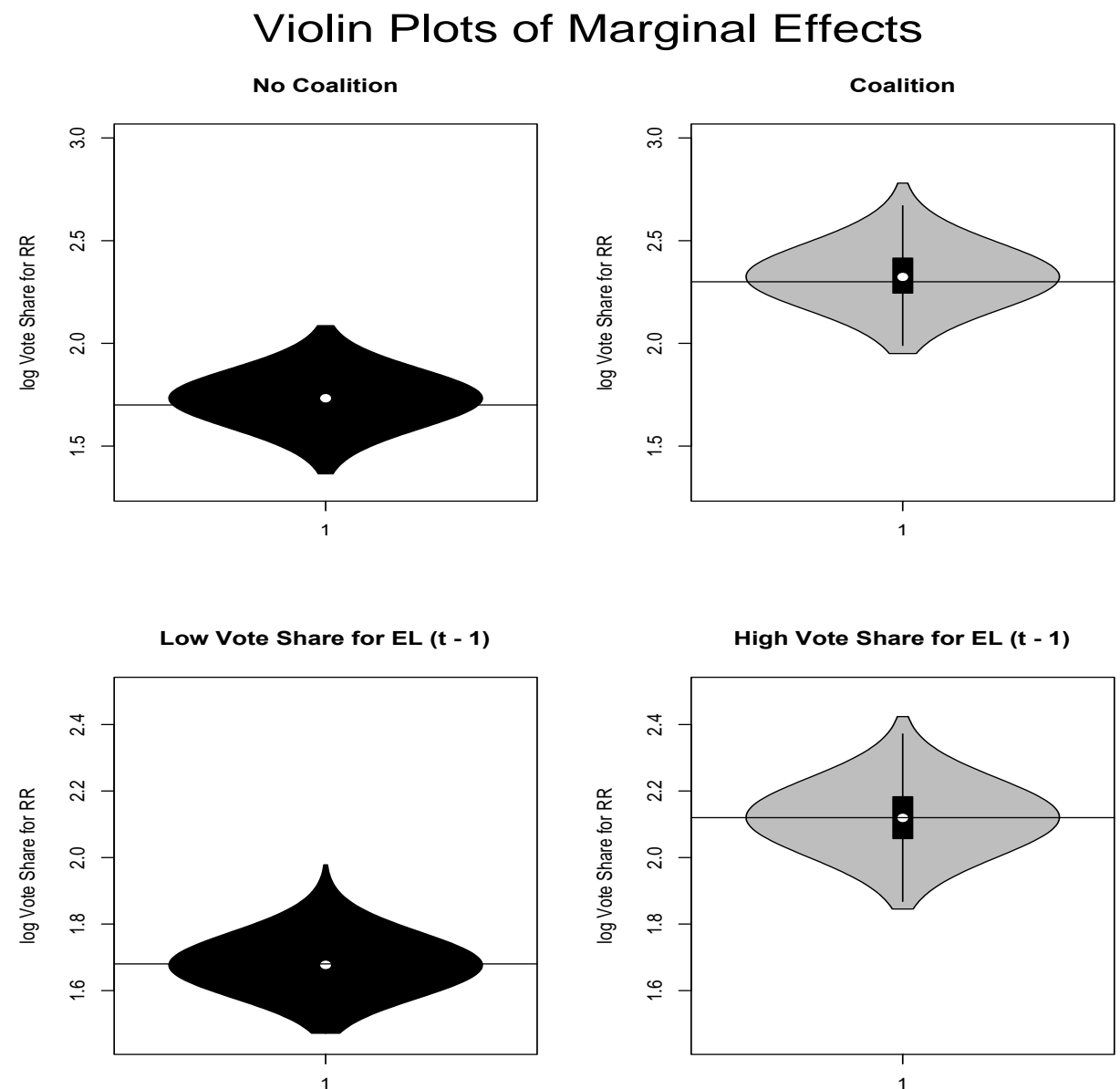

Figure 1: Violin plots with marginal effects based on censored regression (Table 4, Model 2) 


\section{Notes:}

${ }^{1}$ I use the term radical, rather than extremist, to connote a party that does not challenge the democratic order of a given country (Carter, 2005).

${ }^{2}$ While radical right parties in Western Europe often target immigrants, this is less the case in Eastern Europe.

${ }^{3}$ This paper explores peacetime electoral dynamics, and does not seek to explain politics at the time of the collapse of the communist regimes (Bunce 1999).

${ }^{4}$ Eastern European radical right parties support redistribution (Bustikova \& Kitschelt, 2009), whereas Western European radical right parties span the spectrum from the economic right to the left (Mudde, 2007). Grid/group framework is helpful in deciding whether some of the former unreformed communist parties qualify as radical right parties (Ishyiama, 2009).

${ }^{5}$ Social-liberal parties are rare. They support multiculturalism as well as social and economic inclusion of Roma.

6 The complete list of parties, an explanation of the classification procedures and additional material can be found in the on-line appendix: <bustikova.faculty.asu.edu>.

${ }^{7}$ This excludes the first or initial elections and elections that were boycotted.

${ }^{8}$ The size of the titular majority and the size of the minority are unrelated to vote shares for ethnic parties. Countries with larger minorities do not have stronger ethnic parties. Moreover, vote shares for ethnic parties fluctuate over time even though group size is relatively constant over time. 
${ }^{9}$ The absolute ideological extremism of the ethno-liberal party is measured on the basis of the manifesto data and the score is based on positions expressed in the manifesto of the ethno-liberal party. The ideological extremism of the ethno-liberal party is indexed against its proximate competitor, a moderate, mainstream party that also supports the accommodation of minorities. The greater the distance between the two parties, the greater the relative ideological extremism of accommodation advocated by the ethnoliberal party.

${ }^{10}$ In the rare case that there are two radical right parties in one electoral system, it is measured as a cumulative vote share of all radical right parties.

${ }^{11}$ The maximum likelihood estimator in censored regression with fixed effects is widely understood to be biased and inconsistent when $\mathrm{T}$, the length of the panel, is small and fixed. Since the random effect model is superior, there is no need to perform a Hausman test for fixed versus random effects.

12 Source: Transparency International Slovakia, author's interviews in Slovakia, 2007, 2008.

${ }^{13}$ Minority size is based on the census in each country. While perceived group size may differ in some cases from actual group size, unfortunately the lack of data for the time period and countries analyzed here does not allow for testing this hypothesis.

${ }^{14}$ To examine the model's predictive performance on out-of-sample data, I used a crossvalidation experiment to compare the Heckman and the censored approach, and found that the censored approach consistently performed better (Efron \& Tibshirani, 1993). 
${ }^{15}$ I have tested for the interaction effect between the coalition presence of the ethnoliberal party and its vote share in the previous cycle and found the interaction insignificant. Myriad factors, including wealth, changes in wealth, changes in wealth indexed to 1990 levels of development, inflation, government expenditures, growth in government expenditures, welfare state development proxies, and both levels and changes in levels of these variables, all have no independent effect on the electoral strength of the radical right parties.

${ }^{16}$ I tested for the assumption that the censoring limit depends on the same distribution as the uncensored observations, which in our case is any vote share, even very small, for any radical right party that contested the election. I tested Cragg's corner solution model by using a two equation system where the first equation estimates the probability of being above the censoring limit (the minimal number of vote shares) and the second is a truncated regression on the uncensored observation, all vote shares observed. The likelihood ratio test statistic was 15.6, which is an equivalent of the 0.05 critical value of chi-square with eight degrees of freedom. This led me not to reject the null hypothesis that the restricted model (e.g. censored regression) is true.

${ }^{17}$ I assume that higher portions of the party Manifestos (coded as quasi-sentences) that advocate multiculturalism and tolerance for minority views indicate more ideological intensity. There are a number of missing codings in the Manifesto project, especially with regard to the evaluations of small ethno-liberal and small radical right parties, which reduces the sample size. Since missing manifestos are conflated with no radical right parties contested elections, I decided against the implementation of the censored model. 
18 The same result is obtained for the relative ideological intensity of the ethno-liberal party.

${ }^{19}$ While most of the variables in Table 4, Table 5 and Table 6 are consistent across the models, the incumbency effect of the radical right parties inclusion in the government is not confirmed by an analysis of the manifesto data. This might be due to the lower number of cases included in the analysis and multiple omissions of small parties due to missing data.

${ }^{20} \mathrm{I}$ also did not uncover any effect of the radical right party's ideological intensity. The robustness checks included testing for: Ideological convergence of moderate parties (level and change); Absolute ideological extremism of the RR party (level and change); Relative ideological extremism of the RR party (level and change); Ideological extremism of the ethno-liberal party's proximate competitor; Ideological extremism of RR's proximate competitor party. 